\title{
Mediācija un sporta strīdi
}

\author{
Marina Kamen,ecka-Usova \\ Rigas Stradina universitäte, \\ Doktorantüras nodala, \\ doktora studiju programma "Juridiskās zinātnes", Latvija \\ marina_k.usova@yahoo.com
}

\section{Kopsavilkums}

Mūsdienās sports ir daudz vairāk nekā izklaide vai vaḷasprieks, tas ir augsti komercializēta sociāla aktivitāte ar lielu daudzumu dažādu savstarpējo attiecību, kurās nevar iztikt bez strīdiem un konfliktiem. Sportā pierasts veids, kā atrisināt radušos strīdus, ir konflikta atrisināšanu nodot vai nu arbitrāžas tribunālam, piemēram, Sporta arbitrāžas tiesai, vai valsts vai starptautisko federāciju ārējām komitejām (komisijām), piemēram, FIFA Strīdu risināšanas kamerai (FIFA Dispute Resolution Chamber), FIFA spēlētāju statusa komitejai (FIFA Players'Status Committee) vai publiskām tiesām. Abi šie procesi var būt laikietilpīgi un ḷoti dārgi. Rakstā autore piedāvā izskatīt mediāciju kā alternatīvu veidu sporta strīdu risināšanā.

Atslēgvārdi: sports, sporta strīdi, mediācija, sporta tiesības.

\section{levads}

Raksts tika sagatavots, pamatojoties uz sporta tiesību pieaugušo popularitāti un aktualitāti Eiropā un pasaulē. Viena no problemātiskām sporta tiesību jomām ir strīdu risināšana, jo tradicionāla strīdu risināšana vispārējās jurisdikcijas tiesā neatbilst sporta tiesību vajadzībām un nespēj ṇemt vērā to specifiku. Tāpēc strauji attīstās ideja par alternatīvām strīdu risināšanas metodēm un specializētām sporta arbitrāžas tiesām.

Raksta mērḳis ir izpētìt mediāciju kā sporta strīdu risināšanas metodi. Publikācijas sagatavošanai galvenokārt izmantota empīriskā, analītiskā, vēsturiskā un salīdzinošā izpētes metode. 


\section{XXI gadsimta sports un tā specifika}

Mūsdienās sportu var raksturot kā augsti komercializētu sociālu aktivitāti ar lielu daudzumu dažādu savstarpējo attiecību, piemēram, sāncensis un sāncensis; sportists un treneris; sportists un aǵents; sportists un federācija, klubs, komanda; klubs, komanda un aǵents; federācija un atbalstītāji; klubs, komanda un atbalstītāji; klubs un klubs. Pastāvot tik dažādām attiecībām, vērojama augsta nesaskaṇu un strīdu varbūtība. Turklāt, pamatojoties uz İana Blekšova (Ian Blackshaw) sniegto informāciju, sports ir nozīmīga industrija, kas veido vairāk nekā $3 \%$ no starptautiskās tirdzniecības un 1\% no Eiropas Savienības 15 dalïbvalstu kopējā kopprodukta. Tikai ES vien ir radìti aptuveni 2 miljoni darba vietu, kas tiešā vai netiešā veidā ir saistītas ar sportu. Lielbritānijā ikgadējais patērētāju pienesums sporta nozarē ir sasniedzis 12 miljardus mārciṇu [Blackshaw, 2015].

Nīls Gudrums (Neil Goodrum) atzìmē, ka sporta aktivitātes vienmēr tiek iekḷautas vērtīgā un komerciālā industrijā, tādēl domstarpības, kas rodas šajā sakarā, ir daudzveidīgas un sarežgìitas, īpaši n,emot vērā, ka bieži vien sportā saduras publiskās un privātās intereses. Neatkarīgi no tā, vai tas ir saistîts ar spēlētāja līgumiem, sponsorēšanas jautājumiem, būvniecību, televīzijas translācijām, stadiona izmantošanu pēc olimpiskajām spēlēm vai citu, jebkurā strīdā var tikt skarts plašs interešu loks [Goodrum, 2013].

Katras jomas komercializācija ietver ievērojamus ieguldījumus un pieaugošu publikas interesi. Vienlaikus ar sporta komercializāciju pēdējos gados augsto likmju dēl strauji palielinājies arī konfliktu skaits un to atspoguḷojums medijos.

Pieaugušais konfliktu skaits padarīja redzamus trūkumus to risināšanas procesā. Volkers Hesse (Volker Hesse) norādījis, ka sportā pierasts veids, kā atrisināt strīdus, kas radušies saistībā ar noslēgtajiem līgumiem, ir konflikta atrisināša nu nodot vai nu arbitrāžas tribunālam, piemēram, Sporta arbitrāžas tiesai, vai valsts vai starptautisko federāciju ārējām komitejām (komisijām), piemēram, FIFA Strīdu risināšanas kamerai (FIFA Dispute Resolution Chamber), FIFA spēlētāju statusa komitejai (FIFA Players'Status Committee) vai publiskām tiesām [Hesse, 2014]. Abi šie procesi var būt laikietilpīgi un ḷti dārgi. Savukārt N. Gudrums uzskata: lai arī, izmantojot FIFA kameru, ārējiem procesiem parasti ir tā priekšrocība, ka tie ir konfidenciālāki un lētāki par tiesas procesiem, tiem piemìt arī trūkumi - sarežgìita procedūra un fakts, ka lēmumu pien,em trešā persona.

Raksturojot starptautisko sporta strīdu risināšanu publiskās tiesās, kā trūkums ir jāmin arī varbūtība, ka strīds tiks izskatîts vienai pusei svešā jurisdikcijā pēc svešas valsts likumiem. Ja strīds izriet no līgumsaistībām un līgumā puses nav vienojušās, kurai tiesai piemìt strīdu izskatīšana un pēc kuras valsts likumiem tas tiks izskatìts, tad atkarībā no lietas apstākḷiem un pušu domicila tas būs jānosaka pēc Eiropas Parlamenta un Padomes 2012. gada 12. decembra Regulas (ES) Nr. 1215/2012 par jurisdikciju un spriedumu atzī̌anu un izpildi civillietās un komerclietās (Briseles Ibis Regula, ar ko tika aizstāta tās jomā iepriekš darbojusies Padomes Regula (EK) Nr. 44/2001 par jurisdikciju un spriedumu atzišanu un izpildi civillietās un komerclietās noteikumiem) un Eiropas Parlamenta un Padomes Regulas (EK) Nr. 593/2008 par tiesību aktiem, kas piemērojami 
līgumsaistībām (Roma I), noteikumiem vai ar kolīziju normu palīdzību. Gan pirmais, gan otrais ceḷš var novest pie minētajiem trūkumiem - augstām izmaksām par ārvalstu advokātu pakalpojumiem, publiskuma un nenoteikta iznākuma. Vienlaikus strīdu izskatîšanu sportā sarežg̀ì publisko un privāto interešu mijiedarbība, kā arī sporta sacensību bieži vien pārnacionālais raksturs [Goodrum, 2013].

\section{Mediācija sporta strīdu risināšanā}

Juridiskajā literatūrā var rast daudz sporta strīda definīciju, tomēr autore uzskata, ka izsmel̦ošas definīcijas ir krievu zinātniekiem. Jekaterina Pogosjana (Екатерина Погосян) ar sportu saistìto strīdu izprot kā domstarpības par savstarpējām tiesībām un pienākumiem starp sporta attiecībās iesaistītajiem subjektiem, kā arī strīdus, kas rodas ārpus sporta attiecībām, tomēr ietekmē sportistu tiesības un pienākumus kā sporta attiecību subjektus (Погосян, 2011). Savukārt Sergejs Aleksejevs (Сергей Алексеев) uzskata, ka šādi strīdi ir jānodod jurisdikcijas iestādei vai arī tie jāizšķir alternatīvā veidā (Алексеев, 2012).

Pēc Sergeja Jurlova (Сергей Юрлов) domām, atkarībā no savstarpējo attiecību rakstura sporta attiecībās var izšḳirt šādus ar sportu saistītos strīdus:

1) strīdi, kas rodas saistībā ar sacensībām: diskvalifikācija, sacensību rezultātu apstrīdēšana, konkrēta sporta veida tehnisko noteikumu pārkāpumi u.c.;

2) strīdi, kas ir saistīti ar dalību sporta federācijā;

3) ar dopinga lietošanu saistīti strīdi;

4) disciplinārie konflikti, kas rodas sportistu, treneru vai citu federācijas locekḷu rīcības kodeksa pārkāpumu dēḷ;

5) ètiskie strīdi, kas rodas neētisku izteicienu lietošanas dēḷ vai nepiemērotas uzvedības dēl publiskās vietās;

6) līgumiskie vai civiltiesiskie strīdi, kas rodas līgumu pārkāpumu dēl (Юрлов, 2015).

Nemot vērā iepriekšminētos faktus un tiesisko attiecību specifiku, sporta strīdi būtu jārisina miermīlīgā cẹ̦ā, ātri, konfidenciāli, un, kas jo īpaši svarīgi - risinājumam būtu jāvedina uz veselīgām un, ja iespējams, neagresīvām attiecībām starp strīdā iesaistītajām pusēm, taisnīgu rezultātu, apzinoties arī citas, strīdā tieši neiesaistītas, personas aizskāruma iespējas, citiem vārdiem sakot, konflikti būtu jārisina "sporta ğimenes" lokā.

Minēto iemeslu dēḷ tradicionālo strīdu risināšanas veidu - tiesas procesu - nevar uzskatīt par optimālu un labāko izvēli, turpretī, izmantojot alternatīvas strīdu risināšanas metodes un pañēmienus, it īpaši mediāciju, iespējams sasniegt vēlamo rezultātu - miermīlīgu, ātru, konfidenciālu un neagresīvu strīda risinājumu sportā, mediācijai veicinot dialogu starp pusēm, lai rastu risinājumu, kas būtu to labākajās interesēs, kā arī laujot izveidot turpmākas sadarbības (sacensību) priekšnoteikumus. Izvēloties mediāciju, jurisdikcijas noteikšanas un strīda izskatǐšanai piemērojama likuma problēma tiešā veidā nepastāv. 
Kā norāda Fēlikss Stefeks (Felix Steffek) un Katrīna Stouna (Katherine V. W. Stone), mediācija, arbitrāža un arī strukturētās sarunas tiek uzskatītas par alternatīviem strīdu izšḳiršanas veidiem. Tomēr vairākas būtiskas iezīmes ḷauj atšḳirt mediāciju no citām alternatīvajām strīdu izškirš̌anas formām:

1) tã ir brīvprātīga, citiem vārdiem sakot, mediācija balstìta uz pušu brīvprātīgu līdzdalìbu;

2) neitrālais starpnieks (mediators) nevis tiesā, bet sistemātiski veicina pušu savstarpējo komunikāciju, lai tās uzṇemtos atbildību par strīda atrisināšanu;

3) mediācijai piemīt elastīgums un plaša noteikta pieeja, kurā var tikt ņemti vērā visi konflikta aspekti neatkarīgi no to juridiskās saistības jeb būtiskuma [Steffek, 2012; Stoun, 2004].

Respektīvi, mediācijas mērḳis ir panākt, lai puses brīvprātīgi sasniedz strīda risinājumu, kuru ir iespējams nostiprināt arī juridiski. Šajā procesā neitrālā trešā puse l̦auj strīda dalībniekiem nonākt pie vienprātības, tādējādi palīdzot pusēm rast konflikta risinājumu ilgtspējīgā un pašu noteiktā ceḷā. N̦emot vērā sporta īpatnības, vēl viena mediācijas priekšrocība var būt tāda mediatora izvēle, kurš pazìst sporta specifiku un spēs veiksmīgāk rast kopēju valodu ar strīdā iesaistìtajām pusēm.

Saskañā ar pētijumu 'Rebooting' the Mediation Directive: Assessing the Limited Impact of its Implementation and Proposing Measures to Increase the Number of Mediations in the EU mediācijas process parasti aizñem vidēji 43 dienas, tādējādi strīda izskatǐšana tiesā ir daudz laikietilpīgāka (sk. 1. attēlu).

Ievērojot apstākli, ka mediācijas procesi ir konfidenciāli, ir grūti iegūt precīzu informāciju par to veiksmīgu risinājumu. Šveices Mediācijas asociācija (Schweizer Dachverband Mediation), balstoties uz 2008. gadā veikto pētījumu, secina, ka mediācijas procesu veiksmīguma rādītājs ir lielāks par $70 \%$. No otras puses, Gerits Horstmeijers (Gerrit Horstmeier) apgalvo, ka par augstiem veiksmīguma rādītājiem mediācijas procesos 75-90 \% tiek ziṇots atkarībā no jomas, kurā mediācija tiek pielietota [Horstmeier, 2013].

Saskaņā ar V. Hesses pētijjumiem sporta sektorā aptaujātās personas (juristi, mediatori, novērotāji u.c.) bija iesaistītas kopumā 117 ar sportu saistitos mediācijas procesos. Tika ziṇots, ka 69 no šiem procesiem ir bijuši veiksmīgi, kas liecina, ka veiksmīguma rādītājs ir lielāks par $65 \%$. Ir jānnem vērā, ka arī pēc neveiksmīga mediācijas procesa puses vēl joprojām var nodot savu strīdu izskatīšanai tiesā, federācijas komitejā vai arbitrāžas tribunālā. Jānemem vērā arī tas, ka gadījumā, ja puses tomēr nav spējīgas pilnībā atrisināt savu konfliktu, mediācija jebkurā gadījumā var palīdzēt efektīvi mazināt strīdā iesaistìto pušu nesaskaṇas un satuvināt puses, tādējādi radot auglīgu augsni nākamajam risinājumam [Hesse, 2014].

Autorei pagaidām neizdevās rast statistiku, lai atspoguḷotu mediācijas veiksmes rādītāju Latvijā, jo mediācija ir diezgan jauna parādība (tikai 2014. gada 18. jūnijā stājās spēkā Mediācijas likums, un 2014. gada 12. augustā stājās spēkā Ministru kabineta noteikumi Nr. 433 "Mediatoru sertifikācijas un atestācijas kārtība"). Ministru kabineta noteikumi paredz, ka mediatoram, kas vēlas strādāt tiesas ieteiktās mediācijas modelī, t. i., kḷūt par sertificētu mediatoru, ir jākārto pārbaudījums sertifikāta saṇemšanai. 


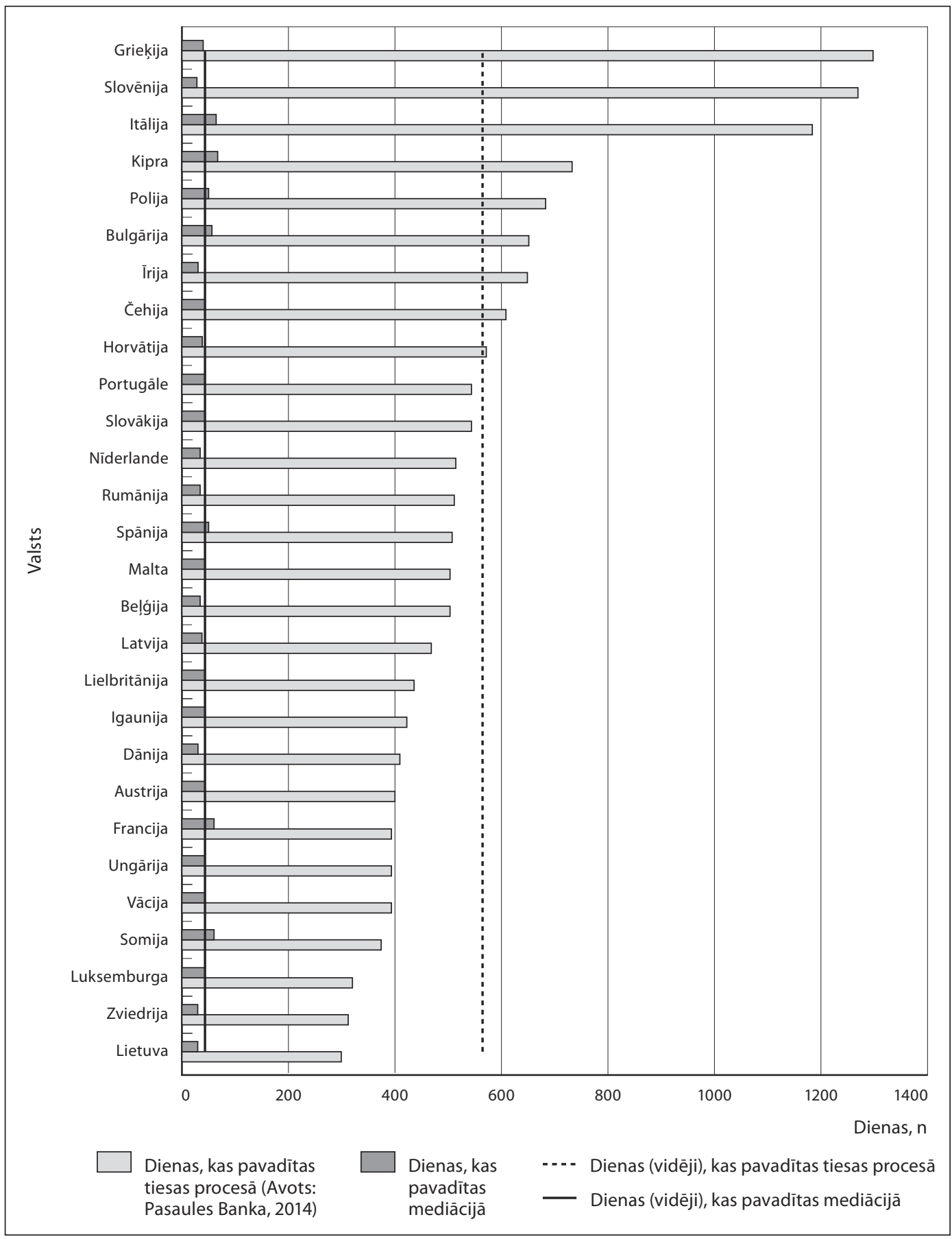

1. attēls. Mediācijas process un strīda izskatǐšana tiesā: salīdzinājums pa valstīm laika aspektā 
Saskaṇā ar portāla www.mediācija.lv datiem pirmais mediatoru sertifikācijas pārbaudījums notika 2014. gada rudenī un 27. oktobrī sertifikātus saṇēma 24 mediatori. Arī pamatojoties uz informāciju, ko sniedz Cietušo atbalsta centrs, kas piedāvā mediatora pakalpojumu, Latvijā mediācijas procesi kḷūst populārāki, kas norāda uz sabiedrības spēju inteligénti un toleranti, ar sapratni, respektējot otru pusi, novērst konfliktus vai, savstarpēji piekāpjoties, atrisināt radušos strīdus.

No Latvijas Republikas Tieslietu ministrijas datiem, kas publicēti mājaslapā www.tm.gov.lv, izriet, ka, izmantojot mediāciju, ir šãdi ieguvumi:

1) tiek ietaupits laiks un nauda;

2) process norit mierpilnā, neformālā gaisotnē, rūpējoties, lai abas puses justos èrti un droši;

3) tiek atjaunota normāla komunikācija starp pusēm, nodrošinot tām iespēju patstāvīgi un konstruktīvi risināt kopīgus jautājumus, kas var rasties nākotnē (it īpaši svarīgi tas ir gadījumos, kad pusēm ir kopīgs viens vai vairāki bērni);

4) puses patstāvīgi pieṇem lēmumus - tas nodrošina, ka tiek pieṇemti tikai tādi lēmumi, ko puses ir akceptējušas un atzinušas par labiem risinājumiem;

5) process ir pilnībā konfidenciāls;

6) pusēm ir tiesības izvēelēties sev pieṇemamu mediatoru un jebkurā laikā atteikties turpināt jau sākto mediācijas procesu;

7) ja strīds jau ticis risināts tiesā, panākot risinājumu mediācijas ceḷā, tiek atmaksāta valsts nodeva $50 \%$ apmērā.

Tātad mediācija pasaulē tiek popularizēta kā alternatīvs strīdu risināšanas veids, un cerams, ka mediācijas veiksmes stāsti ir arī mūsu valstī.

\section{Secinājumi}

Sporta popularizēšana un tā komercializēšana ietekmēja sporta subjektu savstarpējās attiecības, paplašinot tās un padarot tās daudzveidīgākas un specifiskākas. Pēc autores domām, šì tendence pieprasa, lai ar sportu saistìti strīdi tiktu risināti ārpus tiesas ceḷa, proti, arbitrāžas tiesās jeb federāciju ārējās komitejās, strīdu risināšanas komisijās, kas nodrošinātu ātrāku un efektīvāku konflikta atrisināšanu. Mediāciju kā alternatīvu strīdu risināšanas veidu var uzskatìt par piemērotu līdzekli sporta konfliktu veiksmīgai atrisināšanai un konsensusa panākšanai. Par to liecina arī Sporta arbitrāžas tiesas (Court of Arbitration for Sports), kas atrodas Lozannā, Šveicē, prakse un labi pārdomātā un efektīvā mediācijas procedūra sporta strīdu risināšanā. Lai nodrošinātu kvalitatīvu mediācijas procedūru, Sporta arbitrāžas tiesa piedāvā 58 mediatorus, no kuriem 39 ir ar darba pieredzi sporta sektorā, t. i., bijušie tiesneši, sporta federācijas biedri, nacionālās olimpiskās komitejas locekḷi, sporta menedžeri un sporta juristi. Lielākajai dal̦ai no šiem 39 mediatoriem ir arī juridiskā izglīîiba [CAS, 2017]. 
Kā jau tika minēts, ņemot vērā tiesisko attiecību specifiku, sporta strīdi būtu jārisina miermīlīgā ceḷā, ātri, konfidenciāli, un, kas jo īpaši svarīgi - arī risinājumam būtu jāvedina uz veselīgām un, ja iespējams, neagresīvām attiecībām starp strīdā iesaistītajām pusēm, taisnīgu rezultātu, tostarp apzinoties citas, strīdā tieši neiesaistītās, personas aizskāruma iespējas, citiem vārdiem sakot, konfliktus būtu jārisina "sporta gimenes" lokā. Šāds rezultāts noteikti var tikt sasniegts ar mediāciju.

\section{Mediation and Sports Disputes}

\section{Abstract}

Nowadays sport is more than just leisure or hobby, it is a highly commercialised social activity with many interrelations where disputes are inevitable. In sports, the common way to resolve disputes is by submitting the dispute to either an arbitration tribunal, such as the Court of Arbitration for Sport, or to internal committees of national and international federations such as the FIFA Dispute Resolution Chamber/FIFA Players' Status Committee or to public courts. Both of these procedures can be time consuming and cost intensive. The present article considers mediation as an alternative dispute resolution method to resolve sports disputes.

Keywords: sport, sports disputes, mediation, sports law.

\section{Literatūra}

1. Alekseev, S. Sportivnoe parvo Rossii. Pravovye osnovy fizicheskoi kultury i sporta. Moskva: Iuniti-Dana, Zakon i parvo, 2012. (Алексеев, С. Спортивное право России. Правовые основы физической культуры и спорта. Москва: Юнити-Аана, Закон и право, 2012.)

2. Blackshaw, I. The Court of Arbitration for Sport: An International Forum for Settling Disputes Effectively 'Within the Family of Sport'. Interventions. Iegūts no: www.entsportslawjournal.com/ articles/abstract/10.16997/eslj.139/ [sk. 13.10.2017.].

3. Cietušo atbalsta centrs. Mediācija. Iegūts no: http://www.cac.lv/lv/mediacija [sk. 20.10.2017.].

4. Court of Arbitration for Sports (CAS). Iegūts no: http://www.tas-cas.org [sk. 20.10.2017.].

5. Goodrum, N. Mediation in sports disputes: lessons from the UK. Iegūts no: www.lawinsport. com/articles/regulation-a-governance/item/mediation-in-sports-disputes-lessons-from-theuk?highlight=WyJnb29kcnVtI10 [sk. 15.10.2017.].

6. Hesse, V. Is mediation suitable to resolve sport related disputes? Iegūts no: www.lawinsport.com/articles/item/is-mediation-a-suitable-to-resolve-sports-related-disputes?highlight=WyJoZXNzZSJd [sk. 15.10.2017.].

7. Horstmeier, G. Das neue Mediationsgesetz. München: C. H. Beck, 2013.

8. Iurlov, S. Sportivnye spory i ih razreshenie. Teoriia i praktika. Moskva: Infotropik Media, 2015. (Юрлов, С. Спортивные споры и их разрешение. Теория и практика. Москва: Инфотропик Медиа, 2015.) 
9. Mediācija LV. Mediatoru sertifikācija. Iegūts no: http://www.mediacija.lv/?Mediatoru_ sertifik\%C4\%81cija [sk. 20.10.2017.].

10. Pogosian, E. Formy razresheniia sportivnyh sporov: monografiia. Moskva: Volters Kluver, 2011. (Погосян Е. В. Формы разрешения спортивных споров: монография. Москва: Волтерс Ккувер, 2011.)

11. Steffek, F. Mediation in the European Union. An Introduction. Iegūts no: https://e-justice.europa. eu/fileDownload.do?id=b3e6a432-440d... [sk. 15.10.2017.].

12. Stone, K. V. W. Alternative dispute resolution. Encyclopedia of legal history. No: Public Law $\mathcal{E}$ Legal Theory Research Paper Series. Los Angeles: University of California, School of Law, Research Paper 04-30, 2004. 